\title{
The Geo-strategies and Global Peace of Technology on Customer Relationship Management Performance: A Pilot Study among SME's Logistic Operators.
}

\author{
Muhamad Fairos bin Mohamad Shah (Corresponding Author) \\ Universiti Sultan Azlan Shah Bukit Chandan, \\ 33000 Kuala Kangsar Perak Darul Ridzuan \\ No Tel: +6019-4100889 E-mail: mohd.fairos76@gmail.com \\ Samsudin bin Wahab \\ Universiti Teknologi MARA, \\ Cawangan Pulau Pinang, Jalan Permatang Pauh \\ 13500 Permatang Pauh, Pulau Pinang \\ No Tel: +6019-9040180 E-mail: samsudinphd@yahoo.com \\ Mohd Subri bin Tahir \\ Cawangan Pulau Pinang, Jalan Permatang Pauh \\ 13500 Permatang Pauh, Pulau Pinang \\ No Tel: +6012-4544031 E-mail: subri@salam.uitm.edu.my
}

\begin{abstract}
Small and medium enterprises (SMEs) are playing an increasingly important role in sustaining geo strategies and global peace economic growth and logistic system in Malaysia. SMEs also play a very crucial role in customer relationship as they may serve the roles of customer, distributor producer and supplier. However, adaption of customer relationship in Malaysian SMEs has not been fully explored. CRMP model for logistic service presents the combination of technology strategy in term of geo strategies and global peace. The goal of this study is to investigate customer relationship management performance and technology strategy. The dimensions for technology factors are Support information system, information sharing, Usefulness, care/help, ease of use, service portfolio, security and Update System. The populations of study were customers from a logistic company located in Pulau Pinang. Simple random sampling was selected from the target populations. Data collection resulted in 100 respondents to answers questionnaire from
\end{abstract}

the customers of logistic company. Based on the finding, the result showed that, technology strategies are anchor factors in determining geo strategies and global peace on customer relationship management performance. Further study has important managerial implications as the findings will enable management of SMEs to understand progressive and highly varied CRMP practices and contextual factors that contribute to the CRMP as well as geo strategies and global peace and innovative implementation.

Keyword; support information system and information sharing, usefulness, care/help, ease of use, service portfolio, security and update system.

\section{Introduction}

The findings of Muhamad Fairos and Samsudin (2016) in a recent study found that Interactive communication leads to organization performance, it shows the important of technology as a medium interactive between customer and service provider. This is 
another evident that technology factors can be possibly contributed to customer relationship management performance as proposed by this study.

This inconsistency may be due to reinvestigate service quality element in business process together with cost and technology solution towards Customer Relationship Management which represents customer satisfaction (Litvinenko, 2014). They found that service cost and technology solution determine the customer satisfaction towards logistic service among companies in Lithuania.

Many factors might contribute to customer satisfaction and do not limit to service quality but also cost of service and technology solution (Ibrahim et al., 2013). This research reinvestigate Support information system and information sharing, usefulness, care/help, ease of use, service portfolio, security and Update System as well as technology solution towards Customer Relationship Management which represent customer satisfaction geo strategies and global peace.

Previous researches have shown that there are lack of technological innovations in logistics processes at different stages of the customer service (Litvinenko, 2014). Therefore it is compulsory to investigate technology strategies as one of the determinants of customer satisfaction or customer relationship management performance. Geo strategies and global peace technology are important in customer satisfaction for consumers, while selecting from potential providers, evaluate not only service quality (physical), but also the cost of services, servicing, the applied technological solutions, the provider's experience and the range of services.

This finding, while preliminary, suggested by Richard et. al., (2015) stressed that company has to implement CRM system to monitor customer interaction and employee accesses in responding to customer request. This is in line to the concept of maintaining existing customer by avoiding high cost of customer acquisition or customer relationship management performance to be explored in this study. This model indicates that technology factors might contribute to the success of customer relationship management practices by industry as well as an important issue for geo strategies and global peace.

There is a possible influence of technology strategy towards customer relationship management performance in logistic service industry in Malaysia due the judgment in the literature (Muhamad Fairos \& Samsudin, 2016, 2016).

\section{Objective of the Study}

The objective of this study is as follow:

To investigate:

1. The influences of critical technology strategy on Customer Relationship Management Performance of SME's.

\section{Customer Relationship Management Performance.}

Researchers believe that CRMP performance should be measured in terms of supplier behaviours intention since suppliers are the underlying source of value for a company and have the potential to increase the future revenue streams (Martaleni, 2017). Muhammad Nouman et. al. (2015) have suggested five dimensions of value from the supplier's perspective i.e. social, emotional, functional, epistemic, and conditional as providing the best foundation for extending the value construct. Because the primary purpose of CRMP is to increase revenue and supplier lifetime value, supplier behaviours that might bring revenue become strategically important (Bavarsa \& Hosseinipour, 2013) 


\section{Technology Strategy}

It appears that entrepreneurial concept goes beyond what strategic management explains about how firms achieve their objectives (Nurul Izzah et. al., 2015). Logistic SME's can use their soft technology to enhance their relationship with customers. Soft technology such system awareness that allows to SME's to update customer delivery status 24 hours per day. According Zuraimi et. al. (2013) technology is one of the pillar for customer relationship management success hence the system that connected supplier and customer will enhance relationship development within them. Furthermore Litvinenko et. al. (2014) found that usefulness ease of use, security of the system contribute to customer relationship management performance.

The relationship between technology strategy and Customer Relationship Management Performance.

Previous study of Zuraimi et. al. (2013) found several constraints of logistics and supply chains in Malaysia, amongst others; problems in information technology (IT) system with regard to the costly Electronic Data Interchange (EDI) pricing and charges due to in transparent marks-up by freight forwarders, lack of follow up actions after certain meetings or issues raised, lack of sophisticated management techniques among the supply chain companies, and overall performance and functionality of the system, lack of skilled and trained manpower, no single established source of logistics data and information including lack of information of the industry players, facilities, services and capabilities of the sectors, lack of research and development of the industry, lack of regulatory forms to facilitate the industry, and lack of dissemination of information with regard to the development and expansion of the logistics industry. Therefore, geo strategies and global peace are significant to customer relationship management on logistic service provider.
A study conducted by Zuraimi et. al. (2013) in China, found that human resource is one of the constraints as the demand for talent outstripped supply in the logistics industry. Logistics cost is also the constraints as the proportion of the logistics cost to total production cost is estimated at $20-30 \%$ in China, compared to only $10 \%$ in the developed countries (Zuraimi et. al. 2013). Other major logistics barriers in China included; the lack of responsiveness and dependability of local suppliers, inadequate communications infrastructure, complicated and time-consuming customs procedures and the unavailability of logistics consulting services (Zuraimi et. al. 2013).

Even in Singapore which is far ahead of other Asian countries faces some constraints in transport and logistics systems in term of high cost of operations (especially land rental and wages), small geographic space and domestic market, industry was fragmented and lacks scale with very few global players with global aspirations, for instances lack of logistics clusters, lack of responsiveness of customers' needs, shortage of skilled, experienced and entrepreneurial logistics professionals and inadequate technological capabilities to carry out wide range of logistics and supply chain management (Zuraimi et. al. 2013).

\section{Theoretical Background for the Models}

CRM evolved from business processes such as relationship marketing and the increased emphasis on improved customer retention through the effective management of customer relationships (Chen \& Popovich, 2003). The model below presents and supports the idea of many authors on the important of technology and business process in implementing CRM in the organization. 


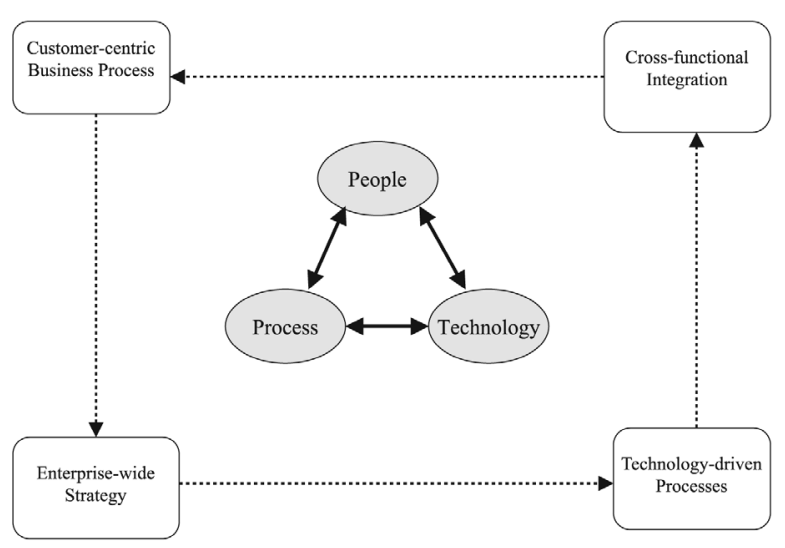

Figure 1: A CRM implementation model [3]

\section{Theoretical Framework}

The current research model proposed a technology strategy as the determinacy of Customer Relationship Management Performance models for SMEs in Malaysia. The complete models proposed are as follows.

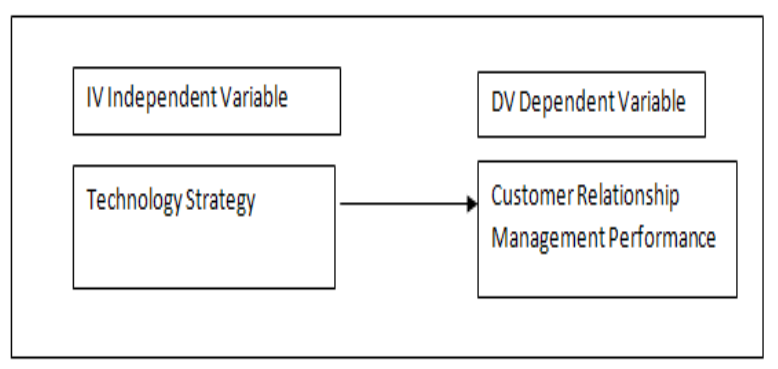

\section{Hypotheses Development}

Muhamad Fairos and Samsudin's (2016, 2016) past researches has investigated the role of provider value in Technology. There is a positive relationship between technology strategy value factor and customer relationship management performance. Therefore, we hypothesized that:

\section{Hypothesis}

There is a relationship between technology strategy factor and Customer Relationship Management Performance.

\section{Methodology}

This research was a pilot test and correlational research in nature. Questionnaire survey was carried out for this research and distributed to the respondents. Population is a target group for logistic service provider by the individual person or the individual customer on the organization. The target population of this pilot test study was one hundred respondents from Pulau Pinang on $\mathrm{a}, \mathrm{b}$ and $\mathrm{c}$ logistic service provider. According to Hair et al., (2006), the number of respondents in pilot test should be at more than thirty.

\section{Results \& Discussion}

\section{Reliability Analysis}

All the variables meet reliability score assumptions which are above 0.6 Cronbach alpha values and Customer Relationship Management Performance 0.648 and Technology Strategy 0.782 . These scores ensure the consistent and stability of independent variable measurement.

Table 1: Model Summary of Regression Analysis

Customer Relationship Management Performance.

Reliability Statistics

Cronbach's Alpha N of items

$\mathrm{N}$ of Items

.648

Based on Table 1, the R Square (R2) result is 0.648 . Thus, the fitness of the model is $64.8 \%$ where firm performance can be predicted by customer relationship management performance.

Table 2: Model Summary of Regression Analysis Technology Strategy

\begin{tabular}{ll} 
Reliability Statistics & \\
\hline $\begin{array}{l}\text { Cronbach's Alpha } \\
\text { N of Items }\end{array}$ & of items \\
\hline 782 & 7 \\
\hline
\end{tabular}


Based on Table 2, the R Square (R2) result is 0.782 . Thus, the fitness of the model is $78.2 \%$ where firm performance can be predicted by technology strategy.

\begin{tabular}{|c|c|c|c|}
\hline & & ts & crmp \\
\hline \multirow[t]{6}{*}{ ts } & Pearson & & \\
\hline & Correlation & & \\
\hline & 1 & .356 & \\
\hline & Sig. (2-tailed) & & .000 \\
\hline & $\mathrm{N}$ & 100 & \\
\hline & 100 & & \\
\hline \multirow[t]{6}{*}{ crmp } & Pearson & .356 & \\
\hline & Correlation & & \\
\hline & 1 & & \\
\hline & Sig. (2-tailed) & .054 & \\
\hline & $\mathrm{N}$ & 100 & \\
\hline & 100 & & \\
\hline
\end{tabular}

\footnotetext{
*. Correlation is significant at the 0.05 level (2-tailed).

**. Correlation is significant at the 0.01 level (2-tailed).

Figure 1: Correlation analysis
}

Table 2 shows a moderate positive of Pearson's Correlations of 0.000 . It means that technology strategy is correlated with firm performance. The significant value is 0.000 which is less than 0.05. Therefore, there is significant relationship between technology strategy and customer relationship management performance which supports the previous study conducted by (Zuraimi et.al. (2013) and Litvinenko (2014)).

Model Summery
\begin{tabular}{|l|l|l|l|l|}
\hline $\begin{array}{l}\text { Model } \\
\text { Estimate }\end{array}$ & $\mathrm{R}$ & R Square & $\begin{array}{l}\text { Adjusted } \\
\text { R Square }\end{array}$ & $\begin{array}{l}\text { Std. Error } \\
\text { of the }\end{array}$ \\
\hline 1 & $.754 \mathrm{a}$ & .569 & .500 & .38040 \\
\hline
\end{tabular}

Figure 2:a. Predictors: (Constant), technology strategy

\section{Conclusion}

Past research has investigated the role of provider value in technology. There is a positive relationship between supplier value factor and technology. This is by looking on technology (Zuraimi et.al., 2013), on customer satisfaction (Richard et. al., 2015), and on online purchasing loyalty (Regina \& Agnes, 2015). The findings of this research indicated that all of the variables have significantly benefited to firm performance. Thus, this shows that the company needs to do innovations from time to time to encourage the growth of geo strategies and sustainability on global peace in industry performance. The current understanding of how aggregated customer relationship management performance attitudes are influenced by important business outcomes is limited (Muhamad Fairos \& Samsudin, 2016). Based on the evidence to date, we conclude that the effort taken by logistic provider will increase customer relationship management performance to meaningful business outcomes and that these relationships support the logistic SMEs sustainability toward geo strategies and global peace. Further research on exploring these issues is sorely needed, and we believe there is potential for longitudinal research in the area of aggregated customer relationship management performance satisfaction. Future study should define CRMP construct from wider and diverse perspectives by encompassing the above dimensions. Finally, in terms of theoretical contributions, this study is mainly given to the geo strategies and global peace toward CRMP field. In short, the study includes a more thorough explanation of information sharing, strategic supplier partnership, customer relationship, practitioner, material flow management, corporate culture in SMEs' policy of CRMP practices.

\section{References.}

A. A. Zuraimi, Mohd Rafi Y.,Mohamed Dahlan I. (2013). Logistics Development in Malaysia East Coast Region: Infrastructure, Constraints and Challenges. International Journal of Trade, Economics and Finance, 4, (5), 325 - 330.

Bavarsa B., Hosseinipour (2013).Studying The Factors Affecting the Customer Relations Management (CRM) in Marun Petrochemical Company. Interdisciplinary Journal of Contemporary Research In Business.4,(11) $845-857$. 
Chen, Popovich, (2003). Understanding customer relationship management (CRM). Business Process Management Journal; 9,(5), 672-688.

]Hair, J.F., Black, W.C., Babin, B.J., Anderson, R.E. (2010). Multivariate Data Analysis.

Meiduté-Kavaliauskienè, Aranskisa A.,Litvinenko M. (2014) Consumer satisfaction with the quality of logistics services. Social and Behavioral Sciences $110,330-340$.

Ibrahim Z., Baharom A. R., Abdul Kadir, O., Noor Azlina, M. Y., Mohd Redhuan, D., \& Mohd Akmal Faiz, O. (2013). The Relationship between Loyalty Program, Customer Satisfaction and Customer Loyalty in Retail Industry: A Case Study. Social and Behavioral Sciences 129, $23-30$.

Muhammad Nouman S., Naveed A., Haider Abbas., Alamdar H. (2015). The Impact of Customer Relationship Management Capabilities On Organizational Performance ; Moderating Role Of Competition Intensity. Arabian Journal of Business and Management Review (Nigerian Chapter) 3(3), 28-47.

Martaleni (2017). Loyalty Program Strategy of Garuda Indonesia Flight Service. International Business Management 11(3), 767-772.

Muhamad Fairos, M. S., Samsudin, W., \& Mohd Subri, T.( 2016). The determinant of Supplier 2 Customer Relationship Management Performance Model for SMEs.T02(047), 1284.
Muhamad Fairos M. S., Samsudin, W., \& Mohd Subri, T. (2016). (M028) Customer-Supplier Relationship Management Performance Model for SMEs: The Integration of Financial and Technology Strategy.Advances of Business Research (ABRIC) 2, (2), 567.

Nurul Izzah, M. S., Liu Yao., \& Damhuji, R. (2015) A review of challenges of logistics management and, barriers of e-business: how Malaysia's efficiency logistics service providers can develop services for e-business? Journal of Scientific Research and Development 2 (13): 100-111.

Tyokyaa, K., Richard., Obunadike, N., Geoergina, \& Lawal, H. (2015). Customer Relationship Management Models for Small and Medium Enterprises in Nigeria. International Journal of Research Studies in Computer Science and Engineering (IJRSCSE) 2, (9), 14-23.

Regina R., Ágnes S. (2015). Factors Affecting the Selection and Implementation of a Customer Relationship Management (CRM). Process Acta Polytechnica Hungarica. 12, (4)183-200. 